\title{
MORPHOLOGICAL RESPONSES OF ORNAMENTAL SUNFLOWER TO PUTRESCINE TREATMENT UNDER DROUGHT CONDITIONS
}

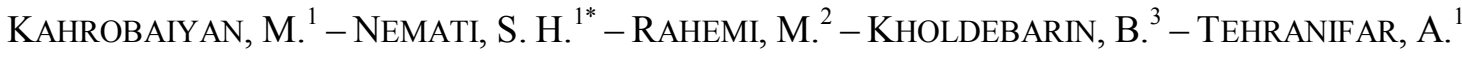 \\ ${ }^{I}$ Department of Horticultural Sciences and Landscape, Faculty of Agriculture, Ferdowsi \\ University of Mashhad, Mashhad, Iran \\ ${ }^{2}$ Department of Horticultural Sciences, Faculty of Agriculture, Shiraz University, Shiraz, Iran \\ ${ }^{3}$ Department of Biology, Faculty of Sciences, Shiraz University, Shiraz, Iran \\ *Corresponding author \\ e-mail:nematish@yahoo.com \\ (Received $1^{\text {st }}$ Aug 2018 ; accepted $16^{\text {th }}$ Jan 2019 )
}

\begin{abstract}
Drought is one of the most important abiotic stresses that affects plant growth and development. Polyamines (PAs) can have an active key role in improving plants tolerance to various stresses. Based on global ecological conditions, plants growing in about one third of the potentially viable lands such as Iran are exposed to drought stress during growing season. The objective of the present study was to investigate the enhancing effects of foliar application of Putrescine (PUT) on short-term tolerance against water stress in ornamental sunflowers. This study was conducted in the experimental greenhouse of the Department of Horticultural Sciences and Landscape, Ferdowsi University of Mashhad, Iran. Plant materials used in this study were the $\mathrm{F}_{1}$ seeds of ornamental sunflower (Helianthus annus L. cv. Sunbright kids). The experiment was conducted as a factorial $(2 \times 3)$ in complete randomized block design with four replications and 8 plants in each replicate. Plants were irrigated at 40 and $80 \%$ field capacity (FC). Foliar spray of PUT $\left(0,75\right.$ and $\left.150 \mathrm{mg} \mathrm{l}^{-1}\right)$ was applied twice during plants growing period. Water stress at $40 \% \mathrm{FC}$ as compared with $80 \% \mathrm{FC}$, significantly affected reproductive and vegetative characteristics of plants. The effects of exogenous application of PUT (75 and $150 \mathrm{mg} \mathrm{l}^{-1}$ ) in comparison with control, significantly increased leaves number per plant, leaves fresh and dry weight, leaves area, stems fresh and dry weight, stems diameters at soil surface, plants height, roots fresh and dry weight, roots area, number of flowers, flowers longevity, seeds number per head and seeds weight. In this study, there was no significant difference between the effects of PUT levels on most of the reproductive and vegetative characteristics of sunflower plants under water stress conditions. The results confirmed that foliar application of PUT protected plants against drought stress and increased specially flowers retention. Therefore, to improve parameters of the studied plants under drought stress, the commercial application of PUT ( $75 \mathrm{mg} \mathrm{l}^{-1}$ ) is recommended for this cultivar.
\end{abstract}

Keywords: flower longevity, Helianthus annus, polyamine, reproductive and vegetative parameters, water stress

\section{Introduction}

About one-third of the global potentially viable lands are subject to an inadequate water supply (Zhang and Huang, 2013). Plants are usually exposed to different environmental stress conditions in their life cycles. Drought is one of the most important abiotic stresses that affect plant growth and development. Decrease in water availability to plants due to low soil water potential followed by leaves transpiration will result in an increase in stomatal resistance, low $\mathrm{CO}_{2}$ influx and a decrease in photosynthesis (Kotakis et al., 2014 and Zgallai et al., 2005).

Polyamines (PAs) have great influence on plant development and stress tolerance (Hussain et al., 2011; Urano et al., 2003). The most important polyamines are diamine 
putrescine (PUT), triamine spermidine (Spd) and tetramine spermine (Spm) (Marco et al., 2011). There is a direct correlation between drought tolerance and the total plants PUT content which is in agreement with the inherent function of PUT in improving drought resistance regardless of plants Spd and Spm contents (Alcázar et al., 2010).

It is believed that the biosynthesis of PAs especially that of PUT will improve plants abiotic stress-tolerance as compared to non-tolerant ones (Hussain et al., 2011). Since cationic PAs' are inherently capable of binding to cellular polyanions including DNA, RNA and proteins, they can influence the synthesis, structure and function of these macromolecules and also by interacting with other cell components, PAs widely affect plant growth and development and also plants responses to environmental stresses (Kanayama and Kochetov, 2015). PAs are involved in signal transduction leading to a change in other hormones (Bitrian et al., 2012), such as Abscisic acid (ABA) (Hussain et al., 2011) and ethylene (Kaur-Sawhney et al., 2003). PAs maintain cell stability (Legocka and Kluk, 2005), and regulate root growth (Wang et al., 2011). It has been found that PA concentrations are higher in the roots and leaves of stressed plants. This implies that PA metabolism in drought-tolerant plants is an adaptive mechanism to drought stress (Zhang and Huang, 2013). Previous studies have shown that there is a close relation between the PUT levels and the biochemical and morphological responses to dehydration. In addition, it has been observed that by manipulating at the transcriptional level, PUT increases ABA biosynthesis in plants in response to drought stress. It has also been reported that PUT accumulation enhances drought tolerance since the levels of Spm and Spd have not increased during the dehydration period (Espasandin et al., 2014).

Considering the adverse climatic conditions in Iran, and plants in landscapes being exposed to drought stress during growing season, the objective of this study was to investigate whether the direct PUT application on ornamental sunflowers plants can enhance short-term tolerance against water stress in such plants.

\section{Materials and methods}

This study was conducted in the experimental greenhouse of the Department of Horticultural Sciences and Landscape, Faculty of Agriculture, Ferdowsi University of Mashhad, Iran, under controlled conditions with relative humidity of $60 \%$, and $25{ }^{\circ} \mathrm{C} / 18^{\circ} \mathrm{C}$ (day/night) temperature. The light intensity inside the greenhouse was 500$700 \mu \mathrm{mol} \mathrm{m} \mathrm{s}^{-1}$. The environmental conditions of the greenhouse were relatively constant during the whole period of the experiments from germination to vegetative and reproductive growth phases.

Plant materials used in this study were the $F_{1}$ seeds of ornamental sunflower (Helianthus annus L. cv. Sunbright kids) purchased from Sokata Company, Japan. Seeds were planted in trays containing coco peat, peat moss and perlite $(1: 1: 1, \mathrm{v} / \mathrm{v} / \mathrm{v})$. After seedlings were at 6 leaf stage (after one month), they were transplanted into plastic pots containing $4.6 \mathrm{~kg}$ of soil, leaf mould, vermicompost and sand $(7: 1: 1: 1$, $\mathrm{v} / \mathrm{v} / \mathrm{v} / \mathrm{v})$. Before starting the experiments, the physical properties of the soil mixture used were determined (Table 1). Forty days after seeds germination, plants were sprayed with Putrescine (PUT) $\left(0,75\right.$ and $\left.150 \mathrm{mg} \mathrm{l}^{-1}\right)$. The amount sprayed was enough to soak the leaves and the solution started to drip and applied 10 times for each plant. Control plants were sprayed with the same amount of distilled water. As the seedlings entered the reproductive phase (60 days after seed germination), soil moisture contents 
were kept at 40 and $80 \%$ field capacity (FC). One month after the first foliar PUT spray (10 days after plants entered the reproductive phase), the second spray was applied, same way as the first one (Figs. 1 and 2). At the end of the experiments, the following morphological characters were determined: Flowers number and diameters (Digital calliper), petals length, flowers longevity on the plants, seeds number and seeds weight in each head, leaves number and area (Leaf Area Meter, Model: L1-3100C. LI-COR Biosciences, USA), plants height and stems diameter at soil surface. Roots area and length and mean roots diameter were measured by Root Analyser (Model: DELTA-T DEVICES LTD. CAMBRIDGE. ENGLAND). Plants aerial parts were cut from soil surface and their roots were washed with tap water to remove the soil. After wiping the moisture, roots were separated from each other and put on the surface of Root Analyser for parameters determination. Also, the fresh weight (FW) and dry weight (DW) of flowers, leaves, stems and roots were determined. Dry weights were determined after keeping the samples in an oven at $75^{\circ} \mathrm{C}$ for $72 \mathrm{~h}$.

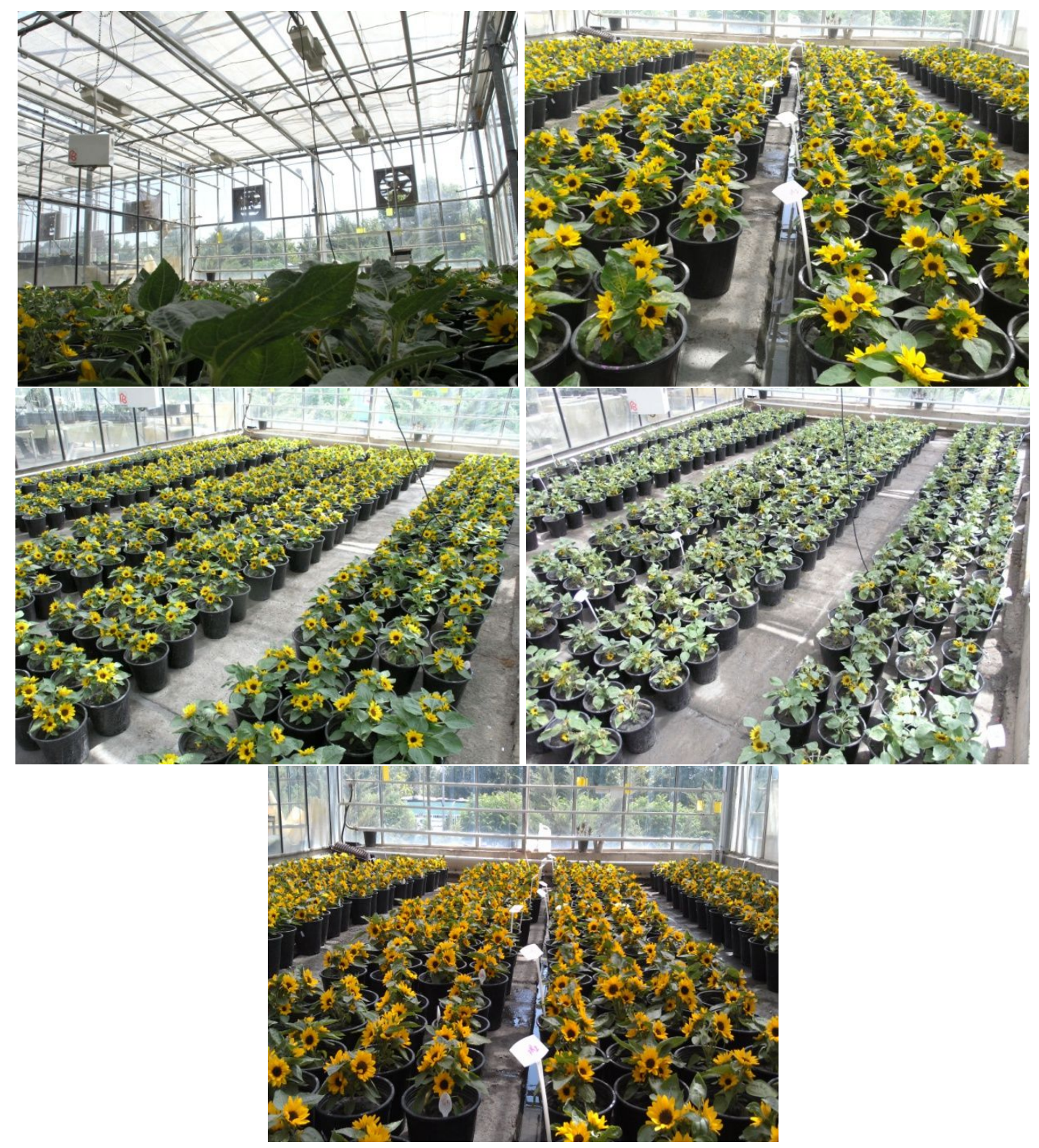

Figure 1. Ornamental sunflower plants used in the experiments 

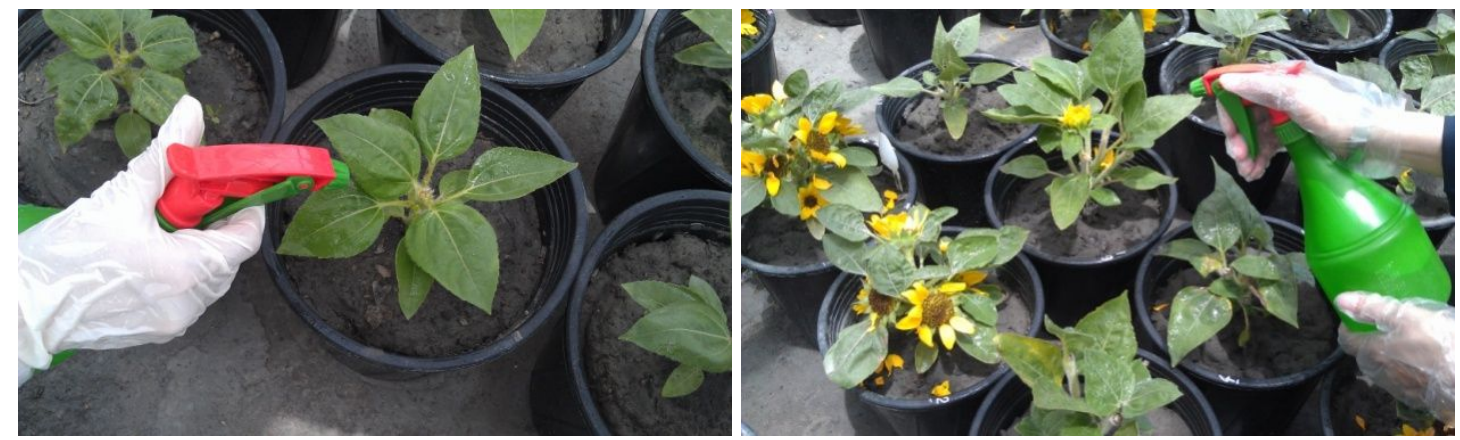

Figure 2. Method used to apply PUT on ornamental sunflower plants

Table 1. Physico-chemical characteristics of the potting soil

\begin{tabular}{c|c|c|c|c|c|c|c}
\hline $\mathbf{E C}(\mathbf{d S} / \mathbf{m})$ & $\mathbf{p H}$ & $\mathbf{N}(\mathbf{\%})$ & $\mathbf{K}(\mathbf{m g} / \mathbf{K g})$ & $\mathbf{P}(\mathbf{m g} / \mathbf{K g})$ & Sand (\%) & Clay (\%) & Silt (\%) \\
\hline 3.53 & 7.15 & 0.1428 & 482.3 & 36.8 & 42 & 18 & 40 \\
\hline
\end{tabular}

The experiments were conducted as a factorial $(2 \times 3)$ in complete randomized block design with four replications and 8 plants in each replicate. Statistical differences between measurements were analyzed following the analysis of variance (ANOVA) using Minitab 16.0 software. Analysis of variance was performed based on Fischer S test. Fischer-LSD test was used to compare means and differences $(P \leq 0.05)$.

\section{Results}

Effects of water stress on plants reproductive characteristics are shown in Table 2 and Figures 3 and 4. Water stress at 40\% FC in comparison with $80 \%$ FC significantly reduced flowers number $(3.26 \%)$, flowers diameter $(8.58 \%)$, petals length $(6.17 \%)$, flowers FW (7.5\%), flowers longevity (11.11\%), seeds number per head (14.38\%) and seeds weight $(50 \%)$.

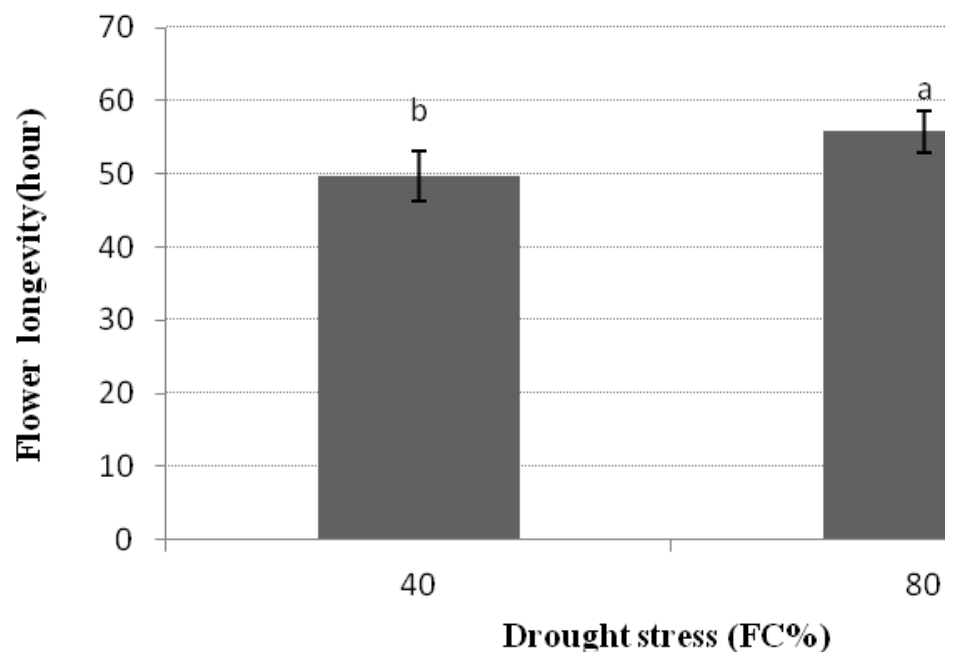

Figure 3. Effects of drought stress on flower longevity. Histograms with different letters are statistically significant based on LSD test at $P \leq 5 \%$ level 


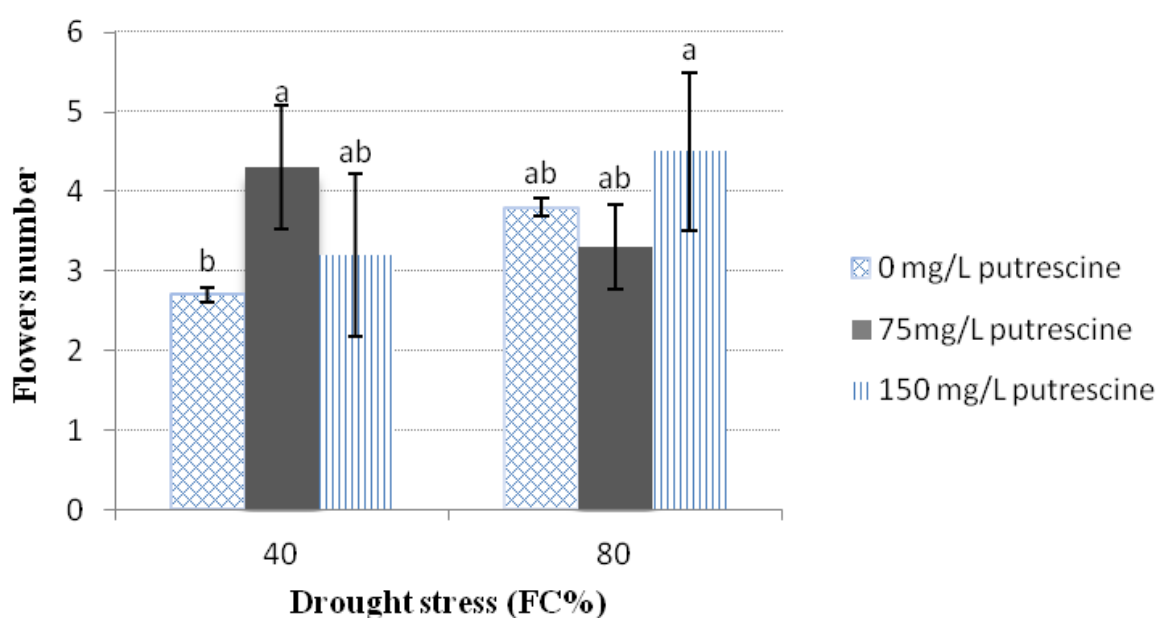

Figure 4. Interaction effects of drought stress levels and Putrescine on flowers number. Histograms with different letters are statistically significant based on LSD test at $P \leq 5 \%$ level

Table 2. Effects of drought stress on flowers parameters

\begin{tabular}{c|c|c|c|c|c|c}
\hline \multirow{2}{*}{$\begin{array}{c}\text { Drought } \\
\text { stress } \\
(\text { FC \%) }\end{array}$} & \begin{tabular}{c} 
Flower \\
\cline { 2 - 6 }
\end{tabular} & $\begin{array}{c}\text { Petal length } \\
\text { diameter (mm) }\end{array}$ & $\begin{array}{c}\text { Flower fresh } \\
\text { weight (g) }\end{array}$ & $\begin{array}{c}\text { Flower dry } \\
\text { weight (g) }\end{array}$ & $\begin{array}{c}\text { Seed } \\
\text { numbers } \\
\text { per head }\end{array}$ & $\begin{array}{c}\text { Seeds } \\
\text { weight (g) }\end{array}$ \\
\hline 40 & $53.3 \mathrm{~b}^{*}$ & $22.8 \mathrm{~b}$ & $4.0 \mathrm{a}$ & $0.5 \mathrm{a}$ & $39.9 \mathrm{~b}$ & $0.1 \mathrm{~b}$ \\
80 & $58.3 \mathrm{a}$ & $24.3 \mathrm{a}$ & $3.7 \mathrm{~b}$ & $0.5 \mathrm{a}$ & $46.6 \mathrm{a}$ & $0.2 \mathrm{a}$ \\
\hline
\end{tabular}

${ }^{*}$ Means with different letters in a column are statistically significant based on LSD test at $P \leq 5 \%$ level

The results of water stress effects on plants vegetative parameters are shown in Tables 3 and 4 and Figure 5. Water stress at 40\% FC in comparison with $80 \%$ FC significantly reduced leaves number per plant $(23.90 \%)$, leaves FW $(37.5 \%)$, leaves DW (32\%), leaves area $(37.08 \%)$, stems FW (35.11\%), stems DW $(28.20 \%)$, stems diameter at soil surface $(15.22 \%)$, plants height $(9.24 \%)$, total roots length $(32.51 \%)$, roots FW (25.30\%), roots DW (15.38\%) and roots area $(27.45 \%)$.

The effects of PUT spray on flower parameters are shown in Table 5 and Figures 4 and 6. PUT at 75 and $150 \mathrm{mg}^{-1}$ in comparison with control, significantly increased flowers number (18.75\% and $37.5 \%$ respectively), flowers longevity $(25.9 \%$ and $9.77 \%$ respectively), seeds number per head (26.2\% and $0.76 \%$ respectively) and seeds weight ( $100 \%$ by both PUT concentrations used).

Table 3. Effects of drought stress on plants vegetative parameters

\begin{tabular}{c|c|c|c|c|c|c|c}
\hline \multirow{2}{*}{$\begin{array}{c}\text { Drought } \\
\text { stress } \\
(\mathbf{F C ~ \% ) ~}\end{array}$} & $\begin{array}{c}\text { Stem diameter } \\
\text { at soil surface } \\
(\mathbf{m m})\end{array}$ & $\begin{array}{c}\text { Stem fresh } \\
\text { weight (g) }\end{array}$ & $\begin{array}{c}\text { Stem dry } \\
\text { weight (g) }\end{array}$ & $\begin{array}{c}\text { Leaves } \\
\text { number per } \\
\text { plant }\end{array}$ & $\begin{array}{c}\text { Leaves } \\
\text { fresh } \\
\text { weight (g) }\end{array}$ & $\begin{array}{c}\text { Leaves } \\
\text { dry } \\
\text { weight (g) }\end{array}$ & $\begin{array}{c}\text { Plants } \\
\text { height } \\
\text { (cm) }\end{array}$ \\
\hline 0 & $7.8 \mathrm{~b}^{*}$ & $17.0 \mathrm{~b}$ & $2.8 \mathrm{~b}$ & $12.1 \mathrm{~b}$ & $8.5 \mathrm{~b}$ & $1.7 \mathrm{~b}$ & $16.7 \mathrm{~b}$ \\
80 & $9.2 \mathrm{a}$ & $26.2 \mathrm{a}$ & $3.9 \mathrm{a}$ & $15.9 \mathrm{a}$ & $13.6 \mathrm{a}$ & $2.5 \mathrm{a}$ & $18.4 \mathrm{a}$ \\
\hline
\end{tabular}

${ }^{*}$ Means with different letters in a column are statistically significant based on LSD test at $P \leq 5 \%$ level 
Table 4. Effects of drought stress on roots parameters

\begin{tabular}{c|c|c|c|c|c}
\hline \multirow{2}{*}{$\begin{array}{c}\text { Drought stress } \\
(\mathbf{F C} \%)\end{array}$} & $\begin{array}{c}\text { Average roots } \\
\text { diameter } \mathbf{( m m )}\end{array}$ & $\begin{array}{c}\text { Total roots } \\
\text { length } \mathbf{( m m )}\end{array}$ & $\begin{array}{c}\text { Roots fresh } \\
\text { weight } \mathbf{( g )}\end{array}$ & $\begin{array}{c}\text { Roots dry } \\
\text { weight } \mathbf{( g )}\end{array}$ & $\begin{array}{c}\text { Roots area } \\
\left(\mathbf{m m}^{\mathbf{2}}\right)\end{array}$ \\
\cline { 2 - 6 } & $0.6 \mathrm{a} *$ & $127273.2 \mathrm{~b}$ & $18.9 \mathrm{~b}$ & $2.2 \mathrm{~b}$ & $76796.0 \mathrm{~b}$ \\
80 & $0.6 \mathrm{a}$ & $188578.2 \mathrm{a}$ & $25.3 \mathrm{a}$ & $2.6 \mathrm{a}$ & $105857.6 \mathrm{a}$ \\
\hline
\end{tabular}

${ }^{*}$ Means with different letters in a column are statistically significant based on LSD test at $P \leq 5 \%$ level

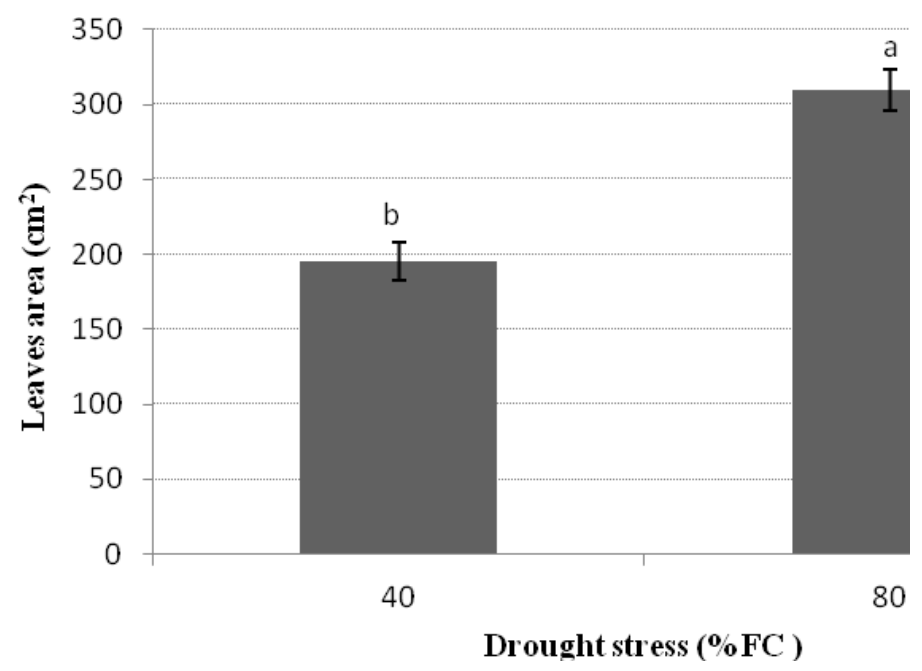

Figure 5. Effects of drought stress on leaves area. Histograms with different letters are statistically significant based on LSD test at $P \leq 5 \%$ level

The effects of exogenous application of PUT on plants under water stress are shown in Tables 6 and 7 and Figure 7. PUT (75 and $150 \mathrm{mg} \mathrm{l}^{-1}$ ) spray in comparison with control (distilled water), significantly increased leaves number per plant $(6.15 \%$ and $16.22 \%$ respectively), leaves $\mathrm{FW}(23.40 \%$ and $29.79 \%$ respectively), leaves DW (15.79\% and $15.79 \%$ respectively) and leaves area (17.58\% and $28.49 \%$ respectively). Also seedlings stems parameters under water stress conditions were affected by Put spray. PUT ( 75 and $150 \mathrm{mg} \mathrm{l}^{-1}$ ) in comparison with control significantly increased stems FW (18.03\% and 36.61\% respectively), stems DW (14.29\% and 39.29\% respectively), stems diameter at soil surface (10\% and $3.66 \%$ respectively), plants height $(5.88 \%$ and $3.53 \%$ respectively), roots FW (23.40\% and $28.72 \%$ respectively), roots DW $(47.37 \%$ and $31.58 \%$ respectively) and roots area (39.06\% and $39.75 \%$ respectively).

Table 5. Effects of Putrescine on flowers parameters

\begin{tabular}{c|c|c|c|c|c|c}
\hline \multirow{2}{*}{$\begin{array}{c}\text { PUT } \\
\left(\mathbf{m g ~ l}^{-\mathbf{1}}\right)\end{array}$} & $\begin{array}{c}\text { Flower } \\
\text { diameter }(\mathbf{m m})\end{array}$ & $\begin{array}{c}\text { Petal length } \\
(\mathbf{m m})\end{array}$ & $\begin{array}{c}\text { Flower fresh } \\
\text { weight } \mathbf{( g )}\end{array}$ & $\begin{array}{c}\text { Flower dry } \\
\text { weight } \mathbf{( g )}\end{array}$ & $\begin{array}{c}\text { Seeds number } \\
\text { per head }\end{array}$ & $\begin{array}{c}\text { Seeds weight } \\
(\mathbf{g})\end{array}$ \\
\hline 0 & $54.4 \mathrm{a} *$ & $23.4 \mathrm{a}$ & $3.7 \mathrm{a}$ & $0.5 \mathrm{a}$ & $39.7 \mathrm{~b}$ & $0.1 \mathrm{~b}$ \\
75 & $58.0 \mathrm{a}$ & $23.8 \mathrm{a}$ & $3.8 \mathrm{a}$ & $0.5 \mathrm{a}$ & $50.1 \mathrm{a}$ & $0.2 \mathrm{a}$ \\
150 & $54.9 \mathrm{a}$ & $23.6 \mathrm{a}$ & $4.0 \mathrm{a}$ & $0.5 \mathrm{a}$ & $40.0 \mathrm{~b}$ & $0.2 \mathrm{a}$ \\
\hline
\end{tabular}

${ }^{*}$ Means with different letters in a column are statistically significant based on LSD test at $\mathrm{P} \leq 5 \%$ level 


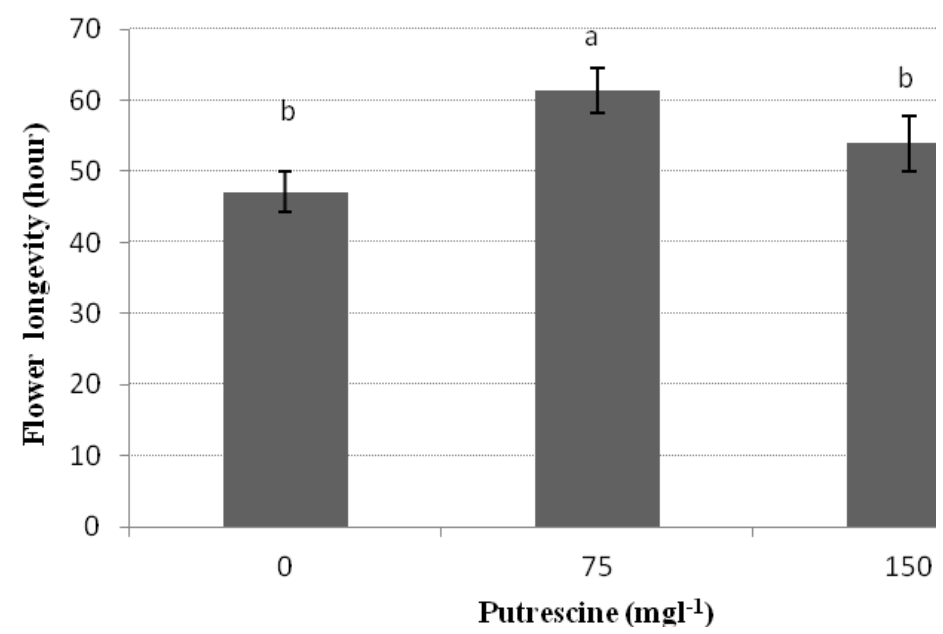

Figure 6. Effects of Putrescine on flower longevity. Histograms with different letters are statistically significant based on LSD test at $P \leq 5 \%$ level

Table 6. Effects of Putrescine on plants vegetative parameters

\begin{tabular}{c|c|c|c|c|c|c|c}
\hline \multirow{2}{*}{$\begin{array}{c}\text { PUT } \\
\left(\mathbf{m g ~ l}^{-1}\right)\end{array}$} & $\begin{array}{c}\text { Stem diameter } \\
\text { at soil surface } \\
(\mathbf{m m})\end{array}$ & $\begin{array}{c}\text { Stem fresh } \\
\text { weight (g) }\end{array}$ & $\begin{array}{c}\text { Stem dry } \\
\text { weight }(\mathbf{g})\end{array}$ & $\begin{array}{c}\text { Leaves } \\
\text { number } \\
\text { per plant }\end{array}$ & $\begin{array}{c}\text { Leaves } \\
\text { fresh } \\
\text { weight }(\mathbf{g})\end{array}$ & $\begin{array}{c}\text { Leaves dry } \\
\text { weight (g) }\end{array}$ & $\begin{array}{c}\text { Plant } \\
\text { height } \\
(\mathbf{c m})\end{array}$ \\
\hline 0 & $8.2 \mathrm{a} *$ & $18.3 \mathrm{~b}$ & $2.8 \mathrm{~b}$ & $13.0 \mathrm{~b}$ & $9.4 \mathrm{~b}$ & $1.9 \mathrm{~b}$ & $17.0 \mathrm{~b}$ \\
75 & $8.7 \mathrm{a}$ & $21.6 \mathrm{ab}$ & $3.2 \mathrm{ab}$ & $13.8 \mathrm{ab}$ & $11.6 \mathrm{ab}$ & $2.2 \mathrm{ab}$ & $18.0 \mathrm{a}$ \\
150 & $8.5 \mathrm{a}$ & $25.0 \mathrm{a}$ & $3.9 \mathrm{a}$ & $15.2 \mathrm{a}$ & $12.2 \mathrm{a}$ & $2.2 \mathrm{a}$ & $17.6 \mathrm{ab}$ \\
\hline
\end{tabular}

*Means with different letters in a column are statistically significant based on LSD test at $P \leq 5 \%$ level

Table 7. Effects of Putrescine on roots parameters

\begin{tabular}{c|c|c|c|c|c}
\hline \multirow{2}{*}{$\begin{array}{c}\text { PUT } \\
\left(\mathbf{m g ~ l}^{-1}\right)\end{array}$} & $\begin{array}{c}\text { Average roots } \\
\text { diameter }(\mathbf{m m})\end{array}$ & $\begin{array}{c}\text { Total roots } \\
\text { length }(\mathbf{m m})\end{array}$ & $\begin{array}{c}\text { Roots fresh } \\
\text { weight } \mathbf{( g )}\end{array}$ & $\begin{array}{c}\text { Roots dry } \\
\text { weight } \mathbf{( g )}\end{array}$ & $\begin{array}{c}\text { Roots area } \\
\left(\mathbf{m m}^{\mathbf{2}}\right)\end{array}$ \\
\hline 0 & $0.6 \mathrm{a} *$ & $118798.9 \mathrm{a}$ & $18.8 \mathrm{~b}$ & $1.9 \mathrm{~b}$ & $72326.0 \mathrm{~b}$ \\
75 & $0.6 \mathrm{a}$ & $171249.0 \mathrm{a}$ & $23.2 \mathrm{ab}$ & $2.8 \mathrm{a}$ & $100578.8 \mathrm{a}$ \\
150 & $0.6 \mathrm{a}$ & $183729.2 \mathrm{a}$ & $24.2 \mathrm{a}$ & $2.5 \mathrm{ab}$ & $101075.6 \mathrm{a}$ \\
\hline
\end{tabular}

${ }^{*}$ Means with different letters in a column are statistically significant based on LSD test at $P \leq 5 \%$ level

In this study, there were no significant differences between the effects of the two PUT levels used on most of the vegetative and reproductive parameters under water stress conditions. It was only the seeds number per head which was affected by the two PUT levels.

The interaction effects of water stress levels (40\% and $80 \%$ FC) and PUT levels (75 and $150 \mathrm{mg} \mathrm{l}^{-1}$ ) significantly increased plants height, flowers number and seeds number per head (Table 8 and Fig. 4). 


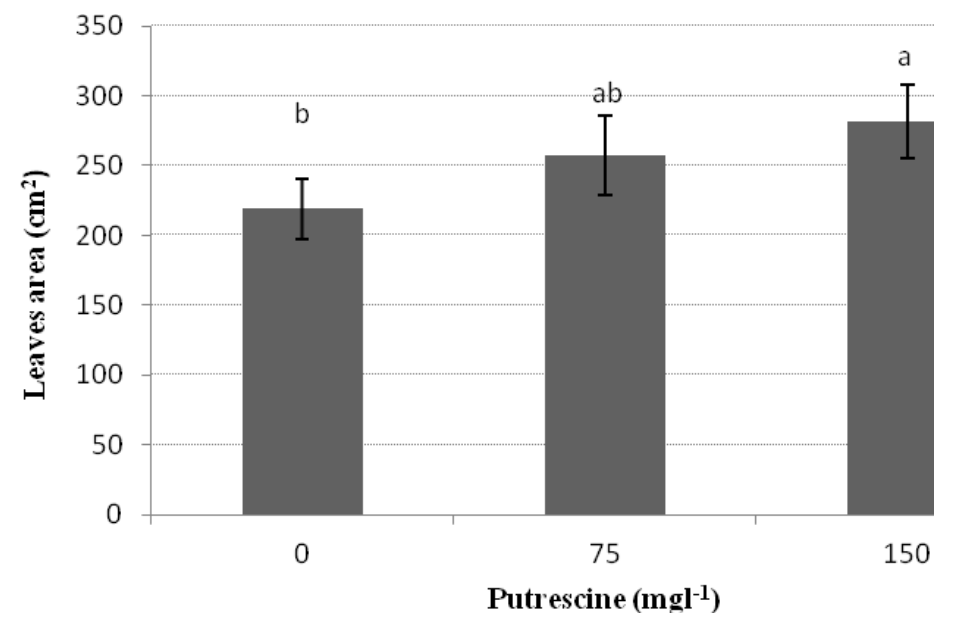

Figure 7. Effects of Putrescine on leaves area. Histograms with different letters are statistically significant based on LSD test at $P \leq 5 \%$ level

Table 8. Interaction effects of Putrescine and drought stress on some plants morphological parameters

\begin{tabular}{c|c|c|c}
\hline \multicolumn{2}{c|}{ Treatments } & \multicolumn{2}{c}{ Parameters } \\
\cline { 2 - 2 } Drought stress & PUT $^{*}$ & \multirow{2}{*}{ Seeds number per head } & \multirow{2}{*}{ Plants height (cm) } \\
\hline \multirow{3}{*}{ DS1 } & 0 & $36.00 \pm 8.34^{\mathrm{bc} * *}$ & $16.60 \pm 0.31^{\mathrm{bc}}$ \\
& 75 & $53.50 \pm 11.64^{\mathrm{a}}$ & $16.60 \pm 0.26^{\mathrm{c}}$ \\
& 150 & $30.40 \pm 10.31^{\mathrm{c}}$ & $17.00 \pm 0.94^{\mathrm{bc}}$ \\
\hline \multirow{3}{*}{ DS2 } & 0 & $43.40 \pm 3.55^{\mathrm{abc}}$ & $17.50 \pm 1.21^{\mathrm{bc}}$ \\
& 75 & $46.80 \pm 6.45^{\mathrm{abc}}$ & $19.40 \pm 0.13^{\mathrm{a}}$ \\
& 150 & $49.60 \pm 4.57^{\mathrm{ab}}$ & $18.30 \pm 1.12^{\mathrm{ab}}$ \\
\hline
\end{tabular}

DS (Drought stress): DS1: 40\%FC; DS2: 80\%FC

${ }^{*}$ PUT $\left(0,75,150 \mathrm{mg} \mathrm{l}^{-1}\right)$

${ }^{* *}$ Data are means \pm SD (standard deviation). Means with different letters in a column are statistically significant based on LSD test at $P \leq 5 \%$ level

\section{Discussion}

In the present study, water stress caused a number of changes in ornamental sunflower plants such as leaves number per plant, leaves area, leaves, stems and roots fresh and dry weight, plants height, roots length and roots area. Leaves drop was significantly higher at $40 \%$ FC as compared with $80 \%$ FC (Table 3 and Fig. 5). Drought induced plant growth inhibition such as plants height and leaves senescence which has also been reported for white clover (Li et al., 2016). The decrease in plants growth and increase in leaves senescence under drought conditions could be due to a decline in plants cytokinin content (Clark et al., 2004; Peleg and Blumwald, 2011). In our study, water stress decreased both plants FW and DW (Tables 2, 3 and 4). The reduction in plants FW under drought stress has also been reported for other plants such as wheat (Rane et al., 2001). The reduction in plants FW under drought stress is mainly due to loss of cell turgor required for cell growth and cell expansion. It has also been reported 
that PAs play important roles in cell division and elongation (Hummel et al., 2004; Mattoo et al., 2010; Paschalidis and Roubelakis-Angelakis, 2005).

The decrease in plants DW in response to drought stress (Tables 2, 3 and 4), is probably due to decline in plant growth, reduction in photosynthetic activity due to increase in stomatal resistance and leaves senescence (Manivannan et al., 2007; Zgallai et al., 2005).

We found that water stress significantly reduced flowers number, flowers diameter and flowers longevity, but foliar application of PUT significantly increased flowers number and flowers longevity (Table 2 and 5 and Figs. 3, 4 and 6). Changes in flower parameters under drought stress, might be due to the cytokinin and gibberellin decline and leaves senescence. Application of PUT somehow counteracted the inhibitory effects of drought stress on flowers parameters (Table 5 and Figs. 4 and 6). It has been reported that increase in endogenous PAs leads to the up-regulation of plants cytokinine and gibberellin biosynthesis mechanisms (Li et al., 2016).

In our study, seeds number and seeds weight per head were significantly reduced by water stress (Table 2). Our results are in agreement with previous reports which have indicated that drought stress increases the ethylene $(\mathrm{ETH})$ evolution rate of wheat grain leading to the inhibition of wheat grain filling (Liu et al., 2016).

It has been reported that external application of PAs is responsible for the increase in endogenous ABA levels (Steiner et al., 2007). Increase in ABA promotes the transport of carbohydrate from stem to the grain (Liu et al., 2016). It has also been reported that increase in PUT accumulation in plants promotes drought tolerance. However, no increase in plants Spm and Spd contents were observed during dehydration period (Espasandins et al., 2014).

Exogenous application of PUT at both concentrations (75 and $150 \mathrm{mg} \mathrm{l}^{-1}$ ) significantly increased most sunflowers plants vegetative and reproductive parameters (Tables 5, 6 and 7 and Figs. 4, 6 and 7). The protective effects of PUT on cell membrane stability index (MSI) and leaves chlorophylls content as well as on photosynthetic activity (PN) have also been reported by Rahemi et al. (2017).

Application of PUT significantly increased flowers retention in sunflower plants (Fig. 6). Similar results have been reported by Baninasab and Rahemi (2008) for flower bud retention in pistachio plants. It has been reported that PAs inhibit the biosynthesis of ETH in plants since S-adenosylmethionine, the precursor of both PA and ETH synthesis will be used mainly for the synthesis of PAs rather than ETH (Liang and Lur, 2002). Exogenous application of PAs has blocked ETH synthesis in rice panicles (Yang et al., 2008).

\section{Conclusion}

Our study has indicated that ornamental sunflower Sunbright kids cultivar, is highly sensitive to water stress. PUT treatments before the onset of drought stress, protects plant against drought and inhibits plants water loss, confirming the key role of PUT in its ability to protect plants against water stress. The effect of exogenous application of PUT (75 and $150 \mathrm{mg} \mathrm{l}^{-1}$ ) in comparison with control, significantly increased leaves number per plant, leaves fresh and dry weight, leaves area, stems fresh and dry weight, stems diameter at soil surface, plants height, roots fresh and dry weight, roots area, number of flowers, flower longevity, seeds number per head and seeds weight. In this study, there was no significant difference between the effects of PUT levels on most of 
the reproductive and vegetative parameters of sunflower plants under water stress conditions. Therefore, to improve the vegetative and reproductive parameters of the studied plants under drought stress, the commercial application of PUT (75 $\left.\mathrm{mg} \mathrm{l}^{-1}\right)$ is recommended for this ornamental sunflower cultivar.

The results of our study originally indicate that PUT treatment under drought conditions improves flowers longevity and other plants parameters such as flowers number and leaves number per plant and leaves area which are important in urban landscape.

The determination of the intercellular titer of PUT and other polyamines and analyses of endogenous plant growth substances such as cytokinine, gibberellins and abscisic acid during experiments are suggested. Furthermore, studying some plants physiological parameters under these conditions such as photosynthetic rate (Pn), transpiration rate $(\mathrm{Tr})$, stomatal conductance of $\mathrm{CO}_{2}$ (gs), stomatal size, plants carbohydrates, proline, chlorophylls and carotenoids contents are recommended.

Acknowledgements. This research was supported by Ferdowsi University of Mashhad. The authors are very grateful to Professor Mehdi Nassiri-Mahallati for his guidance in statistical data analysis.

\section{REFERENCES}

[1] Alcázar, R., Planas, J., Saxena, T., Zarza, X., Bortolotti, C., Cuevas, J., Bitrián, M., Tiburcio, A. F., Altabella, T. (2010): Putrescine accumulation confers drought tolerance in transgenic Arabidopsis plants overexpressing the homologous arginine decarboxylase 2 gene. - Plant Physiol. Biochem. 48: 547-552.

[2] Baninasab, B., Rahemi, M. (2008): Effect of exogenous polyamines on flower bud retention in pistachio. - Korean Soc. Hort. Sci. 49: 149-154.

[3] Bitrián, M., Zarza, X., Alterabella, T., Tiburcio, A. F., Alcázar, R. (2012): Polyamines under abiotic stress: metabolic crossroads and hormonal crosstalks in Plant. - Metabolites 2: $516-528$.

[4] Clark, D. G., Dervinis, C., Barrett, J. E., Klee, H., Jones, M. (2004): Drought-induced leaf senescence and horticultural performance of transgenic PSAG12-IPT petunias. - J. Amer. Soc. Hort. Sci. 129: 93-99.

[5] Espasandins, F. D, Maiale, S. J., Calzadilla, P., Ruiz, O. A. (2014): Transcriptional regulation of 9-cis-epoxycarotenoid dioxygenase (NCED) gene by putrescine accumulation positively modulates ABA synthesis and drought tolerance in Lotus tenuis plants. - Physiol. Biochem. 76: 29-35.

[6] Hummel, I., Gouesbet, G., El Amrani, A., Aïnouche, A., Couée, I. (2004): Characterization of the two arginine decarboxylase (polyamine biosynthesis) paralogues of the endemic subantarctic cruciferous species Pringlea antiscorbutica and analysis of their differential expression during development and response to environmental s. Gene. 342: 199-209.

[7] Hussain, S. S., Ali, M., Ahmad, M., Siddique, K. H. (2011): Polyamines: natural and engineered abiotic and biotic stress tolerance in plants. - Biotechnol. Adv. 29: 300-311.

[8] Kanayama, Y., Kochetov, A. (2015): Abiotic Stress Biology in Horticultural Plants. Springer, Japan.

[9] Kaur-Sawhney, R., Tiburcio, A. F., Alterabella, T., Galston, A. W. (2003): Polyamnines in Plants an overview. - J. Cell. Mol. Biol. 2: 1-12.

[10] Kotakis, C., Theodoropoulou, E., Tassis, K. Oustamanolakis, C., Ioannidis, N. E., Kotzabasis, K. (2014): Putrescine, a fast-acting switch for tolerance against osmotic stress. - J. Plant Physiol. 171: 48-51. 
[11] Legocka, J., Kluk, A. (2005): Effect of salt and osmatic stress on changes in polyamine content and arginine decarboxylase activity in Lupinus luteus seedling. - J. Plant Physiol. 169: 662-668.

[12] Li, Z., Zhang, Y., Zhang, X., Peng, Y., Merewitz, E., Ma, X., Huang, L., Yan, Y. (2016): The alterations of endogenous polyamines and phytohormones induced by exogenous application of spermidine regulate antioxidant metabolism, metallothionein and relevant genes conferring drought tolerance in white clover. - Environmental and Experimental Botany 124: 22-38.

[13] Liang, Y. L., Lur, H. S. (2002): Conjugated and free polyamine levels in normal and aborting maize kernels. - Crop Sci. 42: 1217-1224.

[14] Liu, Y., Liang, H., Lv, X., Liu, D., Wen, X., Liao, Y. (2016): Effect of polyamines on the grain filling of wheat under drought stress. - Plant Physiology and Biochemistry 100: 113-129.

[15] Manivannan, P., Jaleel, C. A., Sankar, B., Kishorekumar, A., Somasundaram, R., Lakshmanan, G. M. A., Panneerselvam, R. (2007): Growht, biochemical modifications and proline metabolism in Helianthus annuus L. as induced by drought stress. - Colloids and Surfaces B: Biointerfaces 59: 141-149.

[16] Marco, F., Alcázar, R., Tiburcio, A. F. P. (2011): Carrasco, Interactions between polyamines and abiotic stress pathway responses unraveled by transcriptome analysis of polyamine overproducers. - OMICS 15: 775-781.

[17] Mattoo, A. K., Minocha, S. C., Minocha, R., Handa, A. K. (2010): Polyamines and cellular metabolism in plants: transgenic approaches reveal different responses to diamine putrescine versus higher polyamines spermidine and spermine. - Amino Acids. 38: 405-413.

[18] Paschalidis, K. A., Roubelakis-Angelakis, K. A. (2005): Spatial and temporal distribution of polyamine levels and polyamine anabolism in different organs/tissues of the tobacco plant. Correlations with age, cell division/expansion, and differentiation. - Plant Physiol. 138: 142-152.

[19] Peleg, Z., Blumwald, E. (2011): Hormone balance and abiotic stress tolerance in crop plants. - Curr. Opin. Plant Biol. 14: 290-295.

[20] Rahemi, M., Rostami, A. A., Kholdebarin, B., Sedaghat, S. (2017): Role of polyamines in caprifig drought tolerance. - Inter: J. Sci. Technol. 6: 822-829.

[21] Rane, J., Maheshwari, M., Nagarajan, S. (2001): Effect of pre-anthesis water stress on growth, photosynthesis and yield of six wheat cultivar different in draught tolerance. Indian J. Plant Physiol. 6: 53-60.

[22] Steiner, N., Santa-Catarina, C., Silveira, V., Floh, E. I. S., Guerra, M. P. (2007): Polyamine effects on growth and endogenous hormones levels in Araucaria angustifolia embryogenic cultures. - Plant Cell Tiss. Org. 89: 55-62.

[23] Urano, K., Yoshiba, Y., Nanjo, T., Igarashi, Y., Seki, M., Sekiguchi, F., YamaguchiShinozaki, K., Shinozaki, K. (2003): Characterization of Arabidopsis genes involved in biosynthesis of polyamines in abiotic stress responses and developmental stages. - Plant Cell Environ. 26: 1917-1926.

[24] Wang, J., Sum, P., Chen, C., Wang, Y., Fu, X., Liu, J. H. (2011): An arginine decarboxylase gene PtADC from Poncirus trifoliata confers abiotic stress tolerance and promotes primary root growth in Arabidopsis. - J. Exp. Bot. 62: 2899-2914.

[25] Yang, J. C., Cao, Y. Y., Zhang, H., Liu, L. J., Zhang, J. H. (2008): Involvement of polyamines in the post-anthesis development of inferior and superior spikelets in rice. Planta 228: 137-149.

[26] Zgallai, H., Steppe, K., Lemeur, R. (2005): Photosynthetic, physiological and biochemical responses of tomato plants to polyethylene glycol-induced water deficit. Journal of Integrative Plant Biology 47: 1470-1478.

[27] Zhang, C., Huang, Z. (2013): Effects of endogenous abscisic acid, jasmonic acid, polyamines, and polyamine oxidase activity in tomato seedlings under drought stress. Scientia Horticulturae 159: 172-177. 